\title{
Analyse titanium surface irradiated with laser, with and without deposited of durapatite ${ }^{1}$
}

\author{
Análise da superfície de titânio sob efeito do laser \\ com e sem deposição de hidroxiapatita ${ }^{1}$
}

\begin{abstract}
Karin Ellen Sisti ${ }^{2}$, Idelmo Rangel Garcia JR. ${ }^{3}$, Antonio Carlos Guastaldi ${ }^{4}$, Andréia C. M. B. Antoniolli ${ }^{5}$, Rafael De Rossi ${ }^{6}$ , Álvaro de L. Brochado Neto ${ }^{7}$

1. Department of Odontology, University Odontology of Araçatuba - State University of São Paulo (UNESP), Brazil.

2. Master, Fellow PhD degree in Post Graduate of Health and Development in the Central West Region, Federal University of Mato Grosso do Sul (UFMS), Brazil.

3. $\mathrm{PhD}$, Associate Professor of the Department of Surgery and Integral Clinic of University of Odontology of Araçatuba UNESP, Brazil.

4. PhD, Associate Professor of the Department of Physic Chemistry of Institute de Chemistry of Araraquara - UNESP, Brazil.

5. PhD, Associate Professor of the Department of Surgery, UFMS, Brazil.

6. PhD, Associate Professor of the Department of Veterinary, UFMS, Brazil.

7. Physiotherapist of Catholic Universit Dom Bosco, Brazil.
\end{abstract}

\begin{abstract}
Purpose: The aim of this study was to analyse the surface of titanium implants using disc irradiated with lasers. Methods: Titanium discs were irradiated with laser high insensitive (Nd-YAG), deposited durapatite and used thermal treatment. Sample received qualitative morphological analyse trough micrographics with many size in SEM (Scanning Electron Microscopy). Results: Surface laser irradiation shows roughness and isomorphic characteristic. The durapatite amplified the titanium surface area by method biomimetic. Conclusion: The surface treatment presented more deposition of durapatite, roughness on the surface, better isomorphic characteristic and increase quantitative in titanium surface area, samples shows rugous, roughness and homogeneity there is not found in the implants available at the market.
\end{abstract}

Key word: Lasers. Titanium . Durapatite.

\section{RESUMO}

Objetivo: Estudar a superfície de implantes osseointegráveis utilizando discos de titânio irradiados com feixe de laser. Métodos: A amostra foi irradiada com feixes de laser de alta intensidade (Nd-YAG), posteriormente depositado hidróxiapatita e submetido a tratamento térmico. Foi analisada sob MEV (Microscópio Eletrônico de Varredura) e realizada análise morfológica qualitativa com microfotografias em vários aumentos. Resultados: A superfície irradiada com laser apresentou deformidade superficial e característica isomórfica; a aplicação de hidroxiapatita pelo método de biomimético aumentou quantitativamente a área da superfície de titânio. Conclusão: A deposição de hidroxiapatita apresentou melhor característica isomórfica e aumento quantitativo da área superficial estudada, a amostra demonstrou características não encontradas nos implantes disposto no mercado.

Descritores: Lasers. Titânio. Durapatita.

\section{Introduction}

The introduction of osseointegration endosseous implants make possible a new rehabilitation in odontology with more comfort to the patients, resulting in better esthetic, phonetic and mastication, providing a better quality of life as well. Since then, a new era in odontology ${ }^{1}$ has started. Branemark, in 1960, introduced the concept of osseointegration in odontology using titanium as implant material and since this date the implantology is the area in odontology that has presented more technological studies, with different types of implants, techniques and biomaterials, leading to a gretaer success in the rehabilitation of edentulous patients ${ }^{2}$. The osseointegration is the direct contact, structural and functional between order bone and the surface implant, in the optical microscopic, showing stable and supporting the masticatory force. $^{2}$ In the biological vision there is no evidence of the direct contact with the bone and the implant, but more or less quantity of fibrous tissue. The resolution of the optical microscopic shows adequate evidence to the osseointegration, although there is no consensus of a definition with biological base. It is acceptable that bone calcification be at $100 \AA$ of the implant, under electronic microscopy. "Osseointegration is the process by which the stable and asymptomatic fixation of 
an aloplastic material in the bone is got and kept during the function". "With the objective of improving or even accelerating this osseointegration, especially in areas with poor quality bone, various studies about titanium implant surfaces were realized in the last decades, and have shown that the recovering with durapatite improve the rigidity of bone and implant interface. $^{4}$ There are various types of treatment of titanium implant surfaces, as titanium plasma-spray, blast of a lot of particles types (sand, glass, aluminum oxide), absorptive biomaterials as micro particles of durapatite, besides, modification with acids or anodization (chemic), and physics, as irradiation with laser high intensity - Nd-YAG ${ }^{3,5}$. In 1960, Theodore Maiman presented the first laser that had the ruby crystal as the active principle. The laser has characteristics that differs it from regular light as monochromaticity, coherence, direction, focalization in little areas and emission of high density energy. ${ }^{6}$ The oxidation or nitretation of titanium surface with laser irradiation is very important because it increases the surface area, and as titanium oxide and titanium nitrate are biocompatible, it becomes possible to use them in the organism. The titanium nitretation is considered bioinert for Food and Drugs Administration (FDA), it increases the capacity of flow off of the implants. The high intensity laser Nd:YAG is used in studies to modify surfaces in titanium implants. ${ }^{5}$ In 2002, titanium implant surfaces were irradiated with laser Nd:YAG in an overheating temperature which changed the original morphologic surface. ${ }^{7}$ Laser Nd:YAG was used over titanium samples and indicated that the potential parameters of laser influence in the melting surface. ${ }^{8}$ In studies of oxidation by laser in titanium surfaces, Lavisse $^{9}$ concluded that the thickness melting layer depends on the amount of emission in same local surface. However, the studies don't kwon which real alteration of surfaces implants with irradiation lasers high intensity and association with durapatite. Based on this, the study was realized using experimental methodology, about titanium discs irradiated with lasers Nd:YAG and deposited durapatite.

\section{Methods}

Sample: 02 discs of titanium, with $4 \mathrm{~mm}$ of diameter and $1,5 \mathrm{~mm}$ of thickness, from Institute of chemistry UNESP - Araraquara. The discs were denominate disc $\mathrm{n}^{\circ} 1$ and $\operatorname{disc} \mathrm{n}^{\circ} 2$.

Procedure: In this study titanium discs were used from Biomaterial Group of Chemistry Institute - UNESPAraraquara. The discs were irradiated with high intensity Nd-YAG laser, and analysed with Scanning Electron Microscopy (SEM).

Disc ${ }^{\circ} 1$ received irradiation of lasers Nd-Yag, with energy of $100 \mathrm{~W} / \mathrm{m}^{2}$, frequency pulse of $35.000 \mathrm{~Hz}$, scanning velocity of $80 \mathrm{~mm} / \mathrm{s}$, pace 1 , matrix space of $+/-0,01 \mathrm{~cm}$ and time almost 2 minutes . Disc $n^{\circ} 2$ received irradiation of lasers the same type that $\mathrm{n}^{\circ} 1$. The parameters of energy, frequency pulse, scanning velocity and pace were the same used in disc $n^{\circ} 1$. There was variation of matrix and time of application, that disc $\mathrm{n}^{\circ} 2$ was almost $0,02 \mathrm{~cm}$ and 1 minute 10 seconds. Deposition of durapatite over titanium: after the laser irradiation the discs were analysed with SEM, and immersed in the solution of SBF (solution body fluid) to durapatite deposition using the biomimetic method. Then the substrates were immersed during
7 days at $37^{\circ} \mathrm{C}$ in the solution $1,5 \mathrm{SBF}$ to grow up. Table 1 displays the ionic concentration of blood plasma and each solution used in this process. For easier interpretation the results of the discs were denominate $1 \mathrm{a}$ and $2 \mathrm{a}$ when received only laser irradiation, $1 \mathrm{~b}$ and $2 \mathrm{~b}$ after deposited durapatite. Morphologic analysis: a qualitative analysis was made with micrographic using SEM, model JSM-T330A, Jeol, from Chemistry Institute, Araraquara - UNESP, with zoom 500, 5.000 and 10.000 X, before and after deposited durapatite. The defects presents and the homogeneity were the question analysed.

\section{Results}

The figures 1, 3 and 5 (disc 1a and disc 2a) present micrographics in SEM of surface sample after laser irradiation. The micrographic with zoom 500X (figure 1) shows melt zone and quick solidification. The figure 2 (discs $1 b$ e $2 b$ ) presents sample micrographics after laser irradiation and deposited durepatite, and show up the presence of durapatite in the zoom $500 \mathrm{X}$, the porous and homogeneity also can be seen in this figure. As disc 1a and disc 2a show up linear defects with diameter $25 \mu$ and homogenates irregularity, however la presents bigger porous and melt zone and quick solidification deeper, and 2 a presents a more homogenous surface.

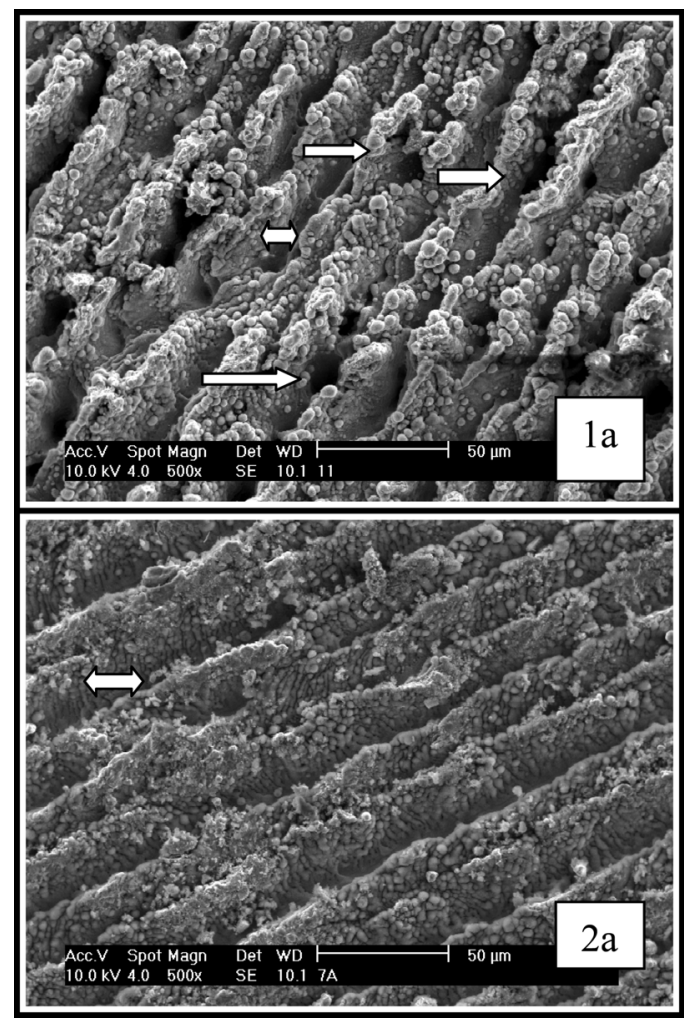

FIGURE 1 - 1a micrographic with disc 1 (lasers condition I) zoom 500X in SEM. Observe zones of melt and quick solidification that results linear defect with $25 \mu \mathrm{m}$ of thickness (double dart). There are porous in the surface (single dart). 2a micrographic do disco 2 (laser condição II) zoom 500X in SEM. Melt and quick solidification zones that proportioned linear defects and homogeneity (double dart). 


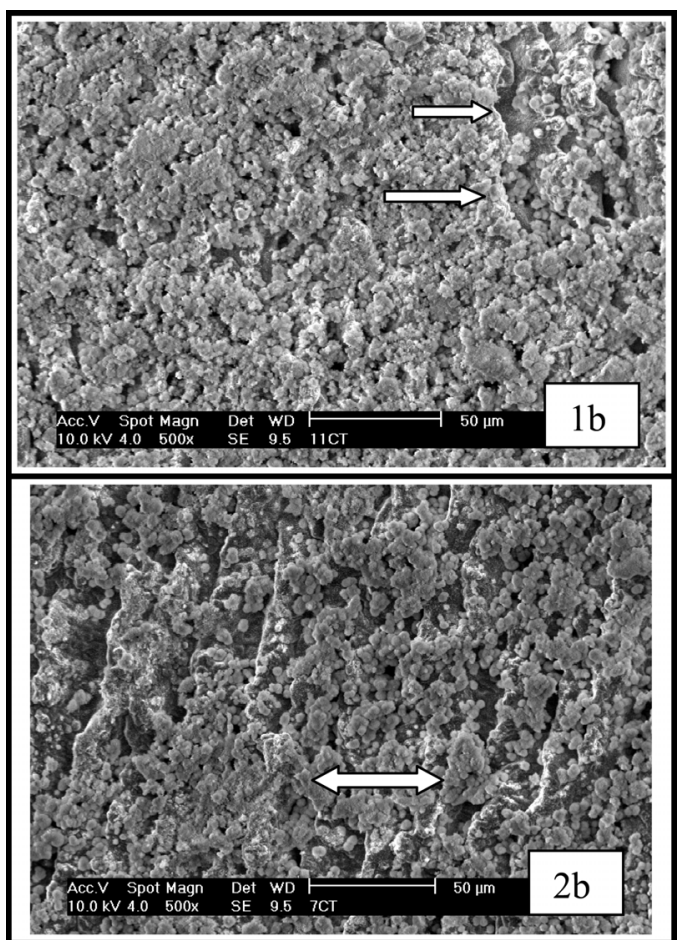

FIGURE 2 - 1b micrographic disc 1(lasers condition I and durapatite deposition) zoom 500X in SEM, observe the durapatite (single dart), roughness surface and homogeneity. $2 \mathrm{~b}$ micrographic disc 2 (laser condition II and durepatite deposition) zoom 500X in SEM, durapatite (double dart) on surface proportioned irregular and roughness surface.

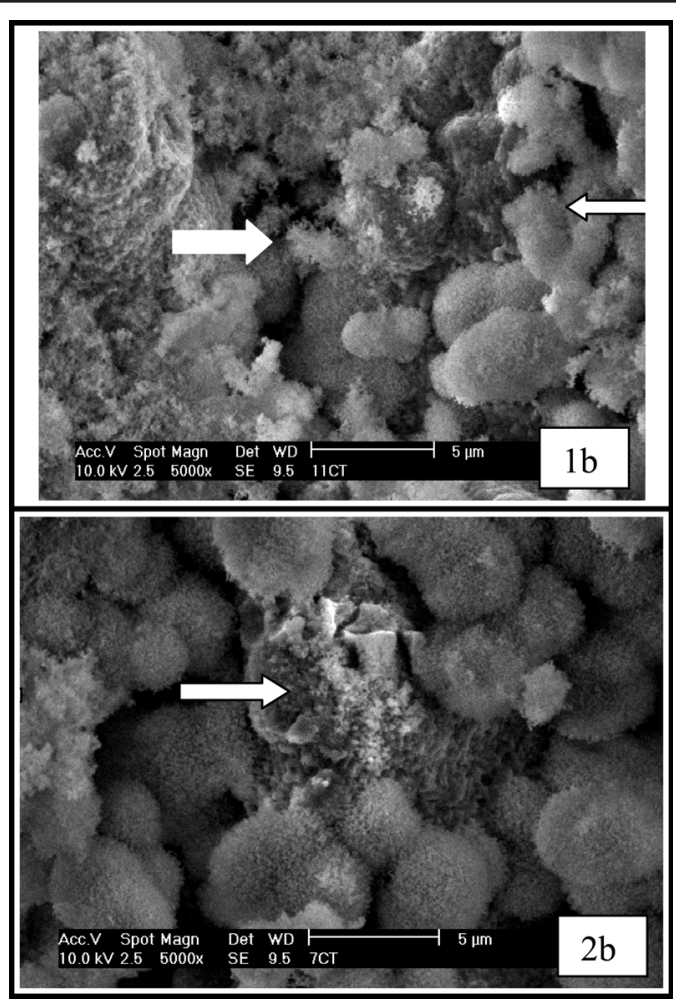

FIGURE 4 - 1 b micrographic disc 1 (laser condition I and with durapatite) zoom 5.000X in SEM, there are durapatite (darts), and roughness. $2 \mathrm{~b}$ micrographic disc 2 (laser condition II and with durapatite) zoom 5.000X in SEM, there are increase surface and durapatite (dart).

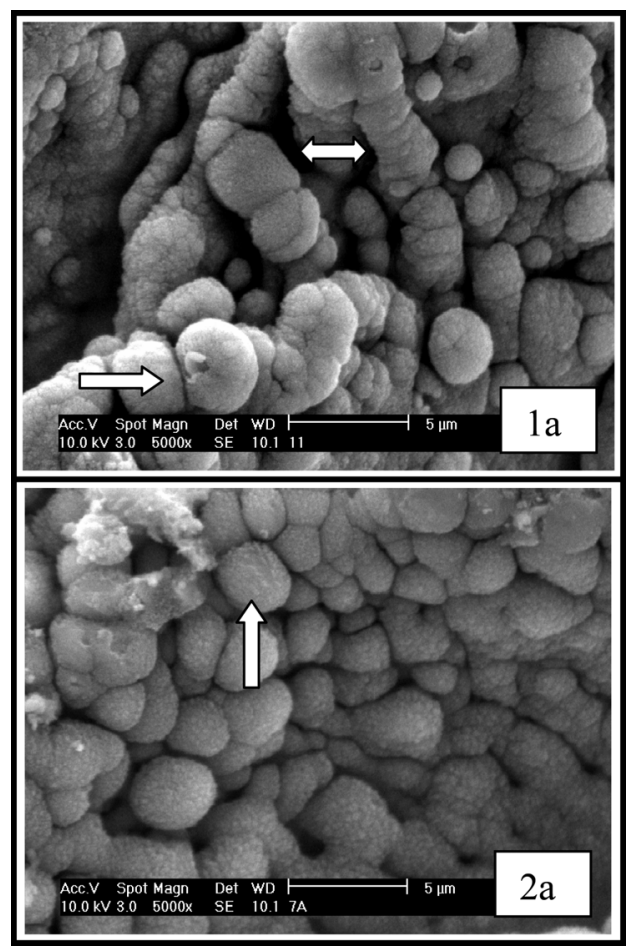

FIGURE 3 - 1a micrographic disc 1 (laser condition I), zoom 5000X in SEM, increase on surface area because irregularity, and formation of spheres (darts). 2a micrographic disc 2 (lasers condition II) zoom 5.000X in SEM, observe increase surface for irregularity and presence of spheres (darts).
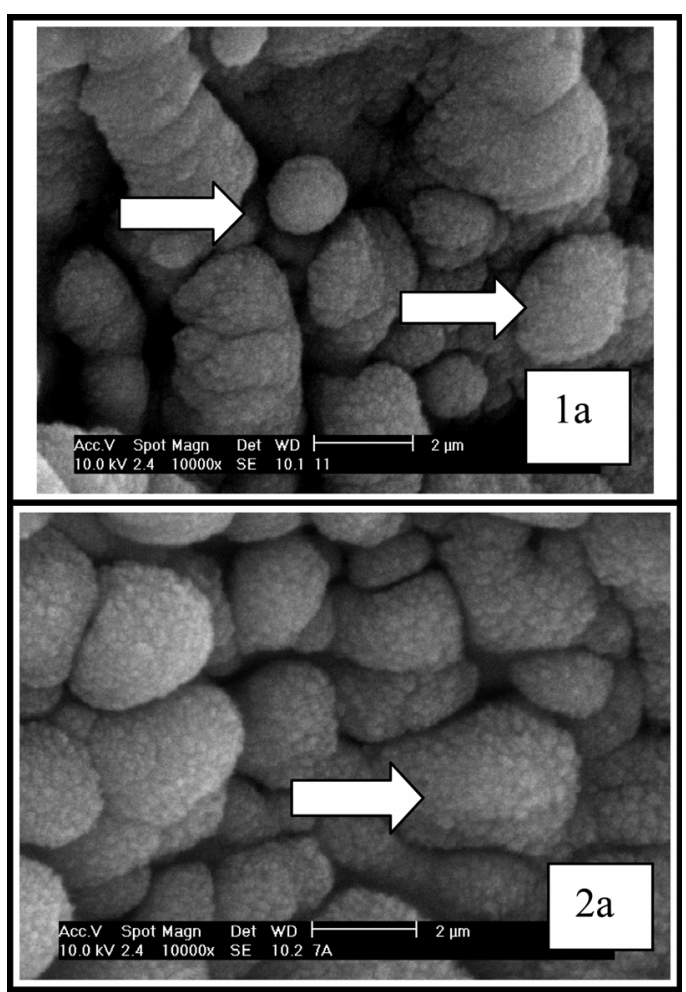

FIGURE 5 - la micrographic disc 1 (laser condition I), zoom 10.000X in SEM, evidence spheres with rugous surface and roughness (darts). 2a micrographic disc 2 (laser condition II), zoom 10.000X in SEM, observe big irregularity and surface rougher on spheres (dart). 


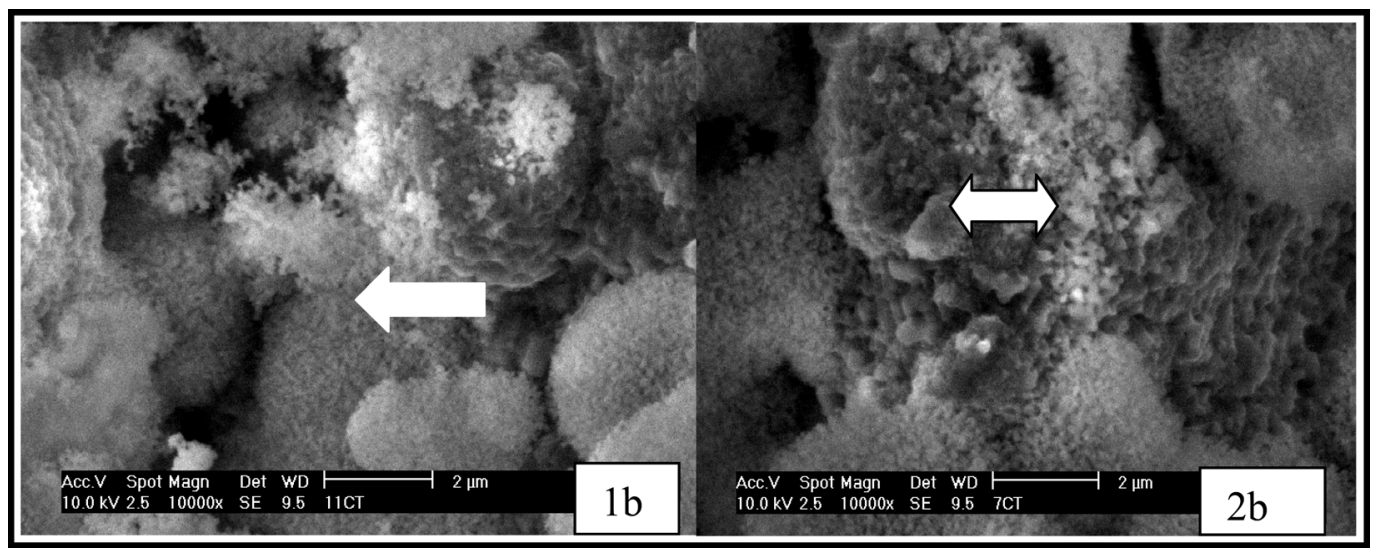

FIGURE 6 - 1b micrographic show the disc 1 (laser condition I and with durapatite), zoom 10.000X in SEM, observe durapatite on spheres (single dart). $2 \mathrm{~b}$ micrographic disc 2 (laser condition and durepatite), zoom 10.000X in SEM, observe the durapatite with characteristic of roughness surface (double dart).

TABLE 1 - Ionic concentration of solution used to cover surface with durapatite (mmol.dm $\left.{ }^{-3}\right)$.

\begin{tabular}{lcclllllll}
\hline & $\mathrm{Na}^{+}$ & $\mathrm{K}^{+}$ & $\mathrm{Ca}^{2+}$ & $\mathrm{Mg}^{2+}$ & $\mathrm{HCO}_{3}^{2-}$ & $\mathrm{Cl}$ & $\mathrm{HPO}_{4}^{2-}$ & $\mathrm{SO}_{4}^{2-}$ & $\mathrm{SiO}_{3}^{2-}$ \\
\hline Blood Plasma & 142,0 & 5,0 & 2,5 & 1,5 & 27,0 & 103,0 & 1,0 & 0,5 & - \\
$\mathrm{SBF}$ & 142,0 & 5,0 & 2,5 & 1,5 & 4,2 & 148,0 & 1,0 & 0,5 & - \\
$1,5 \mathrm{SBF}$ & 213,0 & 7,5 & 3,8 & 2,3 & 6,3 & 223,0 & 1,5 & 0,75 & - \\
$\mathrm{Na}_{2} \mathrm{SiO}_{3}$ & 2,0 & - & - & - & - & - & - & - & 3,6 \\
\hline
\end{tabular}

\section{Discussion}

Delay between the surgery and the prosthesis installation over implants trouble the patients. Nevertheless, the surfaces implants always caused concern and interest in the scientific communities, because the surface has close relationship whit the time, which can alternate from four until six months in machinade surfaces implants, however studies about treatment surface have proved that the time can be decreased. Orsini et $a l^{10}$ made analysis with blast surface implants, machinade and with acid, proved irregular morphologic blast surface, and with acid, which can possibilities the best beginning adhesion cellular, and better osseointegration. Tests about citotoxicity were realized too, and didn't show same toxicity cellular and biocompatibility. Li et $a l^{11}$ wrote about interface bone and endousseous implants with bland and aluminum oxide blast, then concluded that roughness surface can induce the connect bone/fibre perpendicular on surface, during the osseointegration, can improve the interfacial biomechanic and increase the osteoblast function. However study compare, in human, between machinade surface and surface altered with acid, Trisi, at $a l^{12}$ presented the biggest contact in implants that made modification surface with acid, the study was made with SEM and delay with 6 months over 11 patients. Nevertheless, Sykaras ${ }^{13}$ showed as surface as diameter, length, design, material, surface topographic, time and implantation local, and a lot of factories interferer in the osseointegration process. The surface modification also can be realized for electrochemic, with anodic oxidation or for application high intensives lasers. There are same studies using the lasers to prepare the surface implants. In 2002, Gyorgy, et $a l^{8}$ used high intensity lasers to change the titanium surface, and analysed with SEM, that displayed modification in the last layer of titanium. Yue $^{14}$ studied the alloy Ti6A14V surface irradiation with lasers to decrease the corrosion and increase the resistance, presented reduction of corrosion on alloy and there were alteration surface without fractures and with relative malleability. Petö and $\operatorname{col}^{7}$ irradiated the surface titanium implants only machinade and blast surface with $\mathrm{Al}_{2} \mathrm{O}_{3}$ using pulse lasers $\mathrm{Nd}$ :glass, that altered the original morphologic implants surface, was used rabbit tibias and compared with machinade surface with SEM and XPS (photoelectron spectroscopic excited by X-ray), showed that treatment with lasers made the isomorphic topographic and the new bone around presented a good resistance with torch, $20 \%$ more when compare to implants with machinade surface. Hallgren ${ }^{15}$ showed with histomorphmetric that after 12 weeks the quantity of calcificated tissue put on surface irradiated implants was bigger than control group. Cho and Jung ${ }^{16}$ analysed surface irradiated with lasers, in endosseous implants, that showed major torch to remove $62,57 \mathrm{Ncm}$ agaist 23,58 
Ncm on machinade implant, after 8 weeks of surgery, in rabbit tibias. The process of modification titanium surface by irradiation lasers is viable, clean and reproductively, the melt and quick solidification proportionate irregularity in the metal and is controlled for various factors, as parameters lasers sheaf and atmosphere during the irradiation. However in this study can see different surface because lasers Nd:YAG provide homogeneity and irregularity that can improve osseointegration of material. In micrographic 1a (figure 1) display a typical morphologic with melt and quick solidification zones, that are proven to lasers process. This treatment yields porous formation and homogenized surface, that make an increase area and volume, but in the $1 \mathrm{a}$ presents linear defects biggest and deeper that proportionate the increase of contact surface when compare if $2 \mathrm{a}$. However in $\underline{2 \mathrm{a}}$ (figure 5) display a bigger roughness than $\underline{1 \mathrm{a}}$ (figure 5 ). There are homogeneous defect on surface, it is important characteristic in endosseous implants, because optimize the osseointegration (bone tissue without interposition fibre/ tissue). ${ }^{2}$ The sheaf lasers in environment atmosphere alter surface that provide physical and chemical propriety desirable. The durapatite merit eminence because is the principal component mineral of calcificated tissue. The durapatite is the ceramic phosphate or bioceramic, with composition and structure similar to mineral phase of bone and tooph. ${ }^{17}$ Proussaef ${ }^{18}$ in analysis with implants and durapatite after periods of function between 3.5 and 11 years, concluded that durapatite didn't presents reabsorption or dissolution after few ages in function, and probably this occur only when there is contact with soft tissue. Geurs, et $a l^{19}$ analysed characteristics of surface implants in osseointegration process with 3 types of implants: plasma-spray of titanium, durapatite and cylinder with durapatite. Concluded that durapatite pressed the initial tax of osseointegration and presented a decrease faster in the micro-movement when compare with plasma-spray of titanium. Ramires ${ }^{20}$ in study about grown cellular with osteoblast and biomaterials showed that there are precocious aggregation, differentiation and mineralization cellular on $\mathrm{TiO}_{2}$ surface with durapatite. In this study after deposit durapatite on irradiated surface both groups continued presented homogeneity and irregularity, but in the sample $\underline{1 b}$ observed more durapatite deposition (figure 2), roughness surface (figure 4) and more isomorphic characteristic (figure 2) when compare with $\underline{2 b}$ (figure 4), as in $\underline{1 b}$ as in $\underline{2 b}$ comply clearly the presence of durapatite on spheres of surface. The modification of surface in this study provides an increase contact surface and improves the first stability in the endosseous implants and can decrease the osseointegration time. The characteristics phisicochemical of durapatite was evidenced in every groups proportioning more facility in keep the liquid, which improve the quality and accelerate the osseointegration process. Nevertheless, a study with animals could be considerate, to observe the repair around material in the organism.

\section{Conclusion}

The surface treatment presented more deposition of durapatite, roughness, and better isomorphic characteristics; The durapatite application through biomimetic method increased the titanium surface area. The sample showed rugous, roughness and homogeneity there is not found in the implants available at the market.

\section{References}

1. Saadoun AP, Legall ML. Clinical results and guidelines on Steri-Oss Endosseous Implants. Int J Periodont Rest Dent. 1992;12:87-99.

2. Bränemark PI, Zarb GA, Albrektsson T. Tissue Integrated Protheses: osseointegration in clinical dentistry. Chicago: Quintessence; 1985.

3. Zarb GA, Albrektsson T. Osseointegration: a require for the periodontal ligament? Periodont Rest Dent. 1991;11:88-91.

4. Sanz A, Oyarzun A, Farias D, Diaz I. Estudo experimental da resposta óssea a um novo tipo de tratamento de superfície de implantes de titânio. Int J Oral Implantol. 2001;10:20-1.

5. György E, Pérez Del Pino A, Serra P, Morenza JL. Chemical composition of dome-shaped structures grown on titanium by multi-pulse Nd:YAG laser irradiation. Appl Surface Sci. 2003;189:1-8.

6. Cecchini SCM. Estudo in vitro das aplicações do laser de Holmio:YLF em esmalte e dentina, visando a realização de cirurgias de acesso endodôntico e preparo cavitário. [Dissertação Mestrado] Universidade de São Paulo; 1995.

7. Petö G, Karacs A, Pászti Z, Guczi L, Divinyi T, Joób A. Surface treatment of screw shaped titanium dental implants by high intensity laser pulses. Appl Surface Sci. 2002; 186:7-13.

8. György E, Mihailescu IN, Serra P, Pérez Del Pino A, Morenza JL. Single Pulse Nd:YAG laser irradiation of titanium: influence of laser intensity on surface morphology. Surface Coating Technol. 2002;154:63-7.

9. Lavisse L, Grevey D, Langlade C, Vannes B. The early stage of the laser-induced oxidation of titanium substrates. Appl Surface Sci. 2002;186:150-5.

10. Orsini G, Assenza B, Scarano A, Piattelli M, Piattelli A. Surface Analysis of Machined Versus Sandblasted and Acid-Etched Titanium Implants. J Oral Maxillofac Implants. 2000; 15:779-784.

11. Li D, Liu B, Wu J. Bone interface of dental implants cytologically influenced by a modified sandblasted surface: a preliminary in vitro study. Implant Dent. 2001;10(2):132-8.

12. Trisi P, Lazzara R, Rao W, Rebaudi A. Bone-implant Contact and Bone Contact on Machined and Osseotite implant Surfaces. J Int Periodon Rest Dent. 2002;2:2-6. 
13. Sykaras N, Lacopino A, Marker VA, Triplett RG. Woody, RD. Implant Materials, Designs, and surface Topographies: Their Effect on Osseointegration. A Literature Review. Int J Oral Maxillofac Implants. 2000;15:675-690.

14. Yue TM, Yu JK, Mei Z, Man HC. Excimer laser surface treatment of Ti-6Al-4V alloy for corrosion resistance enhancement. Mat Letters. 2002;52:206-12.

15. Hallgren C, Reimers H, Chakarov D, Gold J, Wennerberg A. An in vivo study of bone response to implants topographically modified by laser micromachining. Biomaterials. 2003; 24:701.

16. Cho SA, Jung SK. A removal torque of the lasertreated titanium implants in rabbit tibia. Biomaterials. 2003;24:4859-63.

17. Kawachi EY, Bertran CA, Dos Reis RR. Biocerâmicas: tendências e perspectivas de uma área interdisciplinar. Química Nova. 2000; 23(4):518-22.

18. Proussaef P, Lozada J, Ojano M. Histologic Evoluation of Threaded HA-Coated Root-Form Implants After 3.5 to 11 Years of Function: A Report of Three Cases. Int J Periodont Rest Dent. 2001;21(1):21-9.

19. Geurs NC, Jeffcoat RL, Mcglumphy EA, Reddy MS, Jeffcoat MK. Influence of Implant Geometry and Surface Characteristcs on Progressive Osseointegration. J Oral Maxillofac Implants. 2002;17: 811-15.

20. Ramires PA, Giuffrida A, Mililla E. Three-dimensional reconstruction of confocal laser microscopy images to study the behaviour of osteoblastic cell grown on biomaterials. Biomaterials. 2002;23: 397-406.

\section{Correspondence:}

Rua José Antônio, 2200 - sala 06 79010-190 - Campo Grande - MS - Brazil e-mail: $\underline{\text { sisti@terra.com.br }}$
Conflict of interest: none Financial source: none

\section{How to cite this article:}

Sisti KE, Garcia Jr. IR, Guastaldi AC, Antoniolli ACMB, De Rossi R, Brochado Neto ÁL. Analyse titanium surface irradiated with laser, with and without deposited of durapatite. Acta Cir Bras. [serial on the Internet] $2006 ; 21$ Suppl 4. Available from URL: $\underline{\text { http://www.scielo.br/acb. }}$. 